2016-07-28

Functional and territorial jurisdictions: Regulating a globalized shipping industry

\title{
Howell, KE
}

http://hdl.handle.net/10026.1/5425

\subsection{6/j.jtrangeo.2016.07.010 \\ Journal of Transport Geography}

All content in PEARL is protected by copyright law. Author manuscripts are made available in accordance with publisher policies. Please cite only the published version using the details provided on the item record or document. In the absence of an open licence (e.g. Creative Commons), permissions for further reuse of content should be sought from the publisher or author. 


\title{
Functional and territorial jurisdictions: Regulating a globalized shipping industry
}

\author{
Kerry E. Howell ${ }^{\text {a,* }}$, Syamantak Bhattacharya ${ }^{\text {b }}$ \\ ${ }^{a}$ Graduate School of Management, Plymouth University, UK \\ ${ }^{\mathrm{b}}$ Maritime Science and Engineering School, Southampton Solent University, UK
}

\section{A R T I C L E I N F O}

Article history:

Received 19 November 2015

Received in revised form 19 July 2016

Accepted 23 July 2016

Available online $\mathrm{xxx}$

\section{Keywords:}

Shipping

Functionalism

Ocean space

Regulation

Globalization

Constructivism

\begin{abstract}
A B S T R A C T
Globalization undermines the effectiveness of state-based regulation and implies the need for alternative mechanisms. Regulatory control exercised by international or European institutions provides scope for understanding functionalist rationales when comprehending the construction of 'ocean space'. This paper contributes to appreciating effective functional forms of regulation by investigating the enforcement practices and control in the international maritime tanker industry. Through a study of shipping we explore the extent that functional regulation has been implemented and how this may inform regulatory formation in other industries/sectors affected by global variables. In general, the study suggests that in the context of the shipping industry functionalism has undergone a metamorphosis in terms of normative underpinning; rather than identifying peace as the basis of non-state regulatory initiative it is triggered by wider populist views regarding political ecology (ecopolitics) and environmental sustainability. 'Ocean space' and mobilities are constructed through normative considerations that rely on agencies beyond the nation-state and implementation of regulation through functional variables.
\end{abstract}

(C) 2016 Published by Elsevier Ltd.

\section{Introduction}

Functionalism involves mechanisms for international collaboration through organisations with designated specific tasks that evolve as functional needs change. The system incorporates the premise of peaceful co-operation and the outcome of a pluralist international community where national control is marginalised through functional linkages and rationality. 'Cooperation for the common good is the task, both for the sake of peace and of a better life, and for that it is essential that certain interests and activities should be taken out of competition and worked together' (Mitrany, 1975b: p112). Effectively, even though a normative perspective exists functionalism involves a process of political internationalisation where regulatory decisions are carried out at the most rational or functional level. Mitrany (1975a) considered the continent as the "logical limit of coordination for rail transport (whereas) shipping would be administered in inter-continental terms, while telecommunications, broadcasting and air travel would be organised on an international scale' (p116). Indeed, the 'line of effective organisation (for shipping) ... at once suggests itself as international, or intercontinental, but not universal. A European union could not solve the problem of maritime coordination without the cooperation of America and ... certain other overseas states' (1975b: p107). This perspective advocates a quasi-internationalisation for shipping and this paper investigates the situation regarding the industry following developments in globalization and the European Union (EU). Through a study of shipping and the social construction of 'ocean space' this paper explores the extent that functional regulation or jurisdiction has been implemented and how this may inform developments in regulatory formation and implementation in other functional areas affected by global variables.

Steinberg (2001) understood 'ocean space' as a social construction and considered that human conceptualisations of this space were central to 'the institutions and structures that govern their lives' (p191). Whether or not we are conscious of this process, conceptualisations of the 'ocean space' influence our socio-economic existence. Steinberg (2001) identified that it was necessary for oceans to be recognised as distinct social spaces. 'Ocean spaces' are perceived as 'resource providers' 'battlegrounds' and 'transport surface'. Indeed, the formation and regulation of 'ocean space' is normally premised on realist ideas that identify the nation-state as the repository 'of order and international relations ... characterized by archaic competition' (Steinberg, 2001: p17). In similar contexts mobilities theorists consider that transportation incorporates more than technological issues, but forms and 'forces the structuring of political and social life' (Cidell and Pryterch, 2015: p26). With a similar objective to transportation geography mobilities emphasise the underlying meanings relating to disputed transportation issues. Rather than concentrate on infrastructures, mobilities attend to 'political cultural and aesthetic implications and resonance of movements' ... the meanings ascribed to the movements and the embodied experience of mobilities (Cresswell and Merriman, 2011: p11). This study concentrates on the wider political institutions that govern movement and political interrelationships as well as regulatory structure and implementation.

With reference to 'ocean space' as social construction this paper distinguishes between 'functional jurisdiction' and 'territorial jurisdiction' 
and the difficulties this poses for regulation at the international level, specifically regulation for shipping (Johnson, 1988: p8). Overall, we conclude that although the profit motive provides the driver for effective regulation functional international mechanisms enables effective regulation for shipping in one specific sector 'oil'. Fundamentally, ocean space and mobilities are constructed through normative considerations that rely on agencies beyond the nation-state and implementation of regulation through functional variables.

\section{Functionalism: international and intercontinental approaches}

Notions regarding functional jurisdiction can be found in the work of David Mitrany (1943, 1975a, 1975b, 1975c) where he concentrated on international institutions and perceived their existence as means by which international boundaries may be overlaid by inter-state agencies through which interests would gradually be integrated and international peace realised. There exists a normative perspective relating to peaceful co-existence that may be realised through functional regulation. Indeed, functionalism engenders international welfare which overcomes emotional attachment to the nation-state. Effectively, administration should be undertaken at the most logical level and enable efficient decision making. Organisational networks should be designed to meet a specific social, economic or technical objective. Functionalism provides change through 'linking authority to a specific activity and seeks to break away from the traditional link between an authority and a definitive territory' (Mitrany, 1975a: p125) as well as 'overcome the deep-seated division between the needs of material unity and stubborn national loyalties' (Mitrany, 1975a: p126).

In practice, functionalism is initiated at the intergovernmental or continental level either privately or through the initiatives of state(s) or supranational institutions. Industries with global reach and governments that are unable to deal with international business regulations single-handedly create functional organisations which incorporate international administrative institutions. Whether initiated by the state or supranational level the main impetus of organisational regulation is 'technical self-determination'. This incorporates the increasing autonomy of technical organisations in that 'administrative convenience and efficiency demand that an expert body is not unduly hampered in its investigations by the necessity of constantly new instructions and authorisations' or as Mitrany put it 'certain agencies are born with or achieve "functional autonomy" by virtue of the desirability of such an autonomous status' (cited in Sewell, 1966: p25051). Functional 'needs' in the expression of 'demands' from social groups indicate social and structural goals and means by which these objectives may be realised; these objectives are adhered to by governments and experts, and emphasise common needs rather than individual power. In short, functionalism is about building communities through collective education, technocratic management and regulating beyond the confines of a nation-state.

In response to increasing cross border trade and economic activities involving a wider region this section examines evidence of functionalist approaches using regional institutions. The best example incorporates economic activity in Europe since the creation of the Single European Market (SEM). The SEM propelled individual member states to compromise regulatory activities (Non-Tariff Barriers) to facilitate cross border trade. Through businesses interacting with the regulatory institutions within the European Union (EU) competition gives way to greater cooperation.

Haas (1958) identified this process as neo-functionalism in which regulatory control transferred to new political community; this involved a variant of functionalism where sub-national actors 'in several distinct national settings are persuaded to shift their loyalties, expectations and political activities toward a new centre, whose institutions possess or demand jurisdiction over the pre-existing national states' (1958: p16). Fundamentally, sub-national interests shift their allegiance to a supranational institution. The 'establishment of supranational institutions designed to deal with functionally specific tasks set in motion economic, social and political processes which generate pressures towards further integration' (Tranholm-Mikkelson, 1991: p4). Through European integration and Europeanization a new political community is established that involves member states, EU institutions and subnational actors developing regulatory structures. Indeed, with an appreciation of these theoretical perspectives regarding regulatory formation and implementation beyond the conventional state-based command and control in the next section we turn to the regulatory practices in the shipping industry with an emphasis on the tanker sector.

\section{Regulating ocean space: the shipping industry and tanker sector}

Until the turn of the 20th century the regulation of ocean space largely depended on individual states and initiatives of professional bodies to counter marine insurance claims (Boisson, 1999). However, the international nature of maritime business obliged the sector to look beyond individual state regulations and consider harmonisation at the global level. Common regulations on navigation signals and procedures on rescue in the high seas were early examples of international efforts to bring consistency to maritime regulation. The 1914 international conference on safety of life at sea (an aftermath of the sinking of the Titanic) and the formation of the Inter-Governmental Maritime Consultative Organisation in 1948 under United Nations (which since 1982 has been known as the International Maritime Organisation (IMO)) were major milestones in the development an international regulatory system. Indeed, the IMO stands as a prime example of where maritime nation states came together to seek a form of functional integration (see Gold, 1981 on the development of maritime regulation). Through the IMO, at least at the formation stage, regulatory functional unity can be perceived. However, responsibility for implementing and monitoring regulation is undertaken through individual nation-states (known in the industry as the flag states). This fails to conform to a pure functionalist perspective, which calls for linking authority to a specific activity without having to depend on the traditional role of the nation states. In this way, (until around 1960s) maritime regulation was based on the premise of functionalism but relied on state-based agencies for compliance rather than on inter-continental institutions.

The shipping industry provides a particularly illuminating critical case of globalization and experiences regulatory initiatives of different forms (Sampson and Bloor, 2007). Indeed, the discussion regarding functionalism is timely as state regulatory authorities are faced with considerable challenges in the wake of globalization and growing internationalisation of business activities (Giddens, 1999; Habermas, 2006; Hay and Marsh, 2000; Held et al., 1999). Current debates suggest an acceptance of a more pluralistic form of regulation which includes the functionalist perspective at the supranational, regional and/or global level (Habermas, 2006: p73). Questions need to be addressed regarding mechanisms for developing the regulation of 'ocean space' and relationships with the shipping industry. Indeed, in this context what form of regulation does the shipping industry develop? Does it reflect a form of functionalism and if so does a normative element exist? Furthermore, does the industry reflect a pure form of functionalism and to what extent does a state-centric level persist? Is it more accurate to explain regulatory development and deployment as a form of neo-functionalism? In the following sections of the paper we attempt to deal with these questions through investigating the workings of two forms of functionalism in the maritime tanker sector of the international shipping industry, one originated through principles involving the international dimension and the other using mechanism at the supranational level. A study of regulation formation in a distinct industry can provide an indication of how we may respond to developments of 'ocean space' and mobilities in a globalized world at the international and supranational levels and overcome deficiencies and limitations with territorial jurisdiction. 


\section{Regulating globalization?}

In this section we identify and outline the notion of regulation and position of the Regulation School in relation to issues regarding perspectives of globalization. Regulation may be considered as 'a politicoeconomic concept and, as such, can best be understood by reference to different systems of economic organisation and the legal forms which maintain them' (Majone, 1990: p1-2). Regulation is an attempt to correct market failure in the form of 'monopoly power, negative externalities, failures of information, or insufficient provision of public goods such as law and order or environmental protection' (Majone, 1996: p263). Regulation is 'justified' in so far as it is needed to overcome one or more market 'defects' that might otherwise prevent purely free markets from serving the public interest. Regulation is the sustained and focused control exercised by a public agency over activities that are socially valued (Selznick, 1985). Furthermore, 'market activities can be regulated only in societies that consider such activities worthwhile in themselves and hence in need of protection as well as control' (ibid). Industrial societies generally accentuate a tension between two systems of economic organisation: the market system and the collectivist system. The former is where individuals and sectors are allowed to function with minimal interference in the pursuit of their own goals, whereas the latter looks to control and direct behaviour through intervention.

The Regulation School has been influenced by structural Marxism and identifies economic and social forms that display tensions in existing relations; the school is interested in capital accumulation and how this can be regulated or stabilized through regulatory structures (Aglietta, 1976). Marx and Engels propagated that the economic base or social structures rather that political superstructures or ideological consciousness provide the main means for explaining social transformation. Structural Marxism argued that through deploying regulation the state functions in the long term interest of capitalism and incorporates an entity that regulates class conflict. Structural change could be perceived through historical materialism as well as critical realist ontology and epistemology regarding modes of production and transformation through structured causality. Through regulation the state manages capitalism and may be perceived as a "potential resource or threat to every industry in society. With its power to prohibit or compel, to take or give money the state does selectively help or hurt a vast number of industries' (Stigler, 1971: p3).

An approach within the regulation school involves concerns with international societalization which has drawn on realist and functional perspectives to explore attempts to develop and establish international regimes and global order. 'The expansion of the European Union, other forms of macro-regionalism and growing recognition of the importance of globalization have prompted more general interest in international societalization' (Jessop and Sum, 2006: p30). International societalization identifies similarities or 'complementarities between emerging international structures and strategies to establish a (regulated) global order through international regimes' (ibid). However, neo-liberal perspectives claim that unregulated global free-trade will lead to a general improvement in standards of living; neo-liberal proponents consider that the state should be subordinate to the market and through globalization and free trade all will benefit. 'The more open an economy is to trade, the faster it can catch up with developed countries. And poor people within developing countries will benefit most from trade liberalisation' (Coyle, 2000). However, the opening of trade and financial markets with minimal regulation has resulted in a skewed impact which has benefitted investors and relatively richer countries at the cost of the economically weak and the poorer states. Among critics there exists an anti-globalization feeling that proposes 'a coalition based on resistance to the social decline of the actual or potential losers of structural change and the disempowerment of the democratic state and its citizens' (Habermas, 2006: p81). Consequently, some form of regulation is required to offset the problems that emerge through an unregulated global market for finance, business and (for this study) more specifically shipping e.g. environmental disasters and issues regarding labour, safety and expertise.

Deregulation (or re-regulation) in the recent period of globalization has taken different forms and has affected most sectors and industries especially those spanning national borders. Indeed, one can identify a shift from an orthodox state-led command and control form of regulation toward a more pluralistic structure where different types of nonstate players intervene at different levels (Gunningham and Rees, 1997; Sinclair, 1997; Gunningham and Grabosky, 1998; Gunningham, 1998; Gunningham and Sinclair, 1999; van Erp and Huisman, 2010). Such an approach may be identified as a form of international societalization when understanding the development of regulatory structures. Gibbs et al. (2010) highlighted the importance of taking a 'responsive' approach to regulation which implies state regulation with greater flexibility and strategic intervention. In a similar way, Gunningham (2007) suggests the need for greater self-regulation using, for example, the Safety Case Approach (SCA) where organisations are required to operate within state approved monitored self-regulatory procedures. Likewise, Braithwaite and Drahos (2000) argued for a regulatory concept based on 'network regulation' in which multiple regulatory players are all kept in check by one another. In addition, Siems and Schinder (2014) revisited the concept of 'ordoliberalism' which identified the need for state intervention to maintain order even in economic liberalism. In a slightly different format, Gereffi et al. (2005) underlined the growing evidence of regulatory control exerted by supply chain leaders and the impact on workplace health and safety in an increasingly market-led business world. (Walters and James, 2009) Drawing on arguments relating to global regulation, international societalization and functionalist approaches this paper assesses issues regarding regulation and construction of ocean space through a study of the maritime industry.

\section{Regulating the international maritime industry: international of inter-continental?}

Due to the progressive increase of global free-market, over the last four decades, ship-owners have increasingly chosen to register their ships in countries, such as Liberia, Panama, and Bahamas, commonly known as the Flags of Convenience (FOC) (Ozcayir, 2001). The transfer of assets to FOCs provides a twofold benefit for ship-owners. First, a FOC registered ship enjoys little regulatory oversight from the state, which allows cost efficiencies in terms of low registration fees and maintenance expenses. Second, minimal requirements on the labour standards of FOC also allow ship-owners to employ relatively lowwage seafarers from Eastern Europe, East and South East Asia based on relatively poor employment contracts and working conditions (ILO, 2001).

Since the free market allows ship-owners to choose the 'appropriate' register there is new competition in the business of ship registration among the FOC states as they are keen to acquire more ships for commercial gain through imposing limited regulatory pressure (Alderton and Winchester, 2002). As a consequence of FOCs a number of regulatory initiatives were initiated to mitigate the fallout of flagging out. Among them the Port State Control (PSC) regulation (adopted in 1982) made considerable impact. It gave legislative rights for states to inspect shipboard operational practices and statutory certificates on foreign registered ships which docked in its ports. The first and widely acknowledged as the most effective region for PSC was Europe; this is an intercontinental/international institution (instituted through the Paris Memorandum of Understanding MoU), which provided the structure for shipping regulation development at the European level. The potency of PSC emits from its power to detain ships when deficiencies identified during inspections endangered their safety and could result in accidents or oil pollution (Ozcayir, 2001). The PSC also derived strength and credibility through making inspection results publicly available, categorising 
performances as well as naming and shaming organisations involved with the inspected ships.

Implementation of regulation in the industry followed a structured system under the IMO (as noted above a specialised UN Agency) and involved deliberation between delegates who are mainly representatives of Flag States. Consensus is reached regarding the adoption of internationally agreed regulations and subsequent implementation is monitored by each Flag State (Boisson, 1999). As the process does not involve ship owners the development of the PSC, like other pieces of legislation, did not provide an opportunity to the ship owners to object to the new regime. For the relatively unscrupulous ship owners PSC continues to be seen as a deterrent and over the last three decades there has been considerable interest in enhancing its inspection and control mechanisms from both practitioners (Lowry, 2007) and academics (Heija et al., 2011; Fan et al., 2014).

Indeed, the PSC was coordinated through a regional (continental) approach and institutionalised in Europe. The embryonic PSC took form in 1978 when eight nations from North West European came together through the Hague Memorandum to enforce shipboard living and working conditions as identified by the ILO Convention no. 147. While the Hague Memorandum was being formalised, serious oil pollution from Amoco Cadiz disaster resulted in outcry from the public which influenced politicians from European States together with representatives from the European Commission to include wider safety features for shipping. This disaster was seen as a representation of the declining standards of regulatory compliance brought about through FOCs and the response a call for regulatory control at the supranational level based on an emerging normative perspective in the form of environmentalism (Ozcayir, 2001; Grey, 1996, 2007; Paris, 2012). One may consider that in this context we can observe the relationship between functional and state organisations.

The realisation of the Paris MoU identified inter-continental and international dimensions and was facilitated by the political reshaping of Europe. The benefits of the PSC have been widely acknowledged and regularly reported in the maritime media (Cariou et al., 2008) which suggests that this functional approach to regulation (at least in the European context) was highly effective. Through regional cooperation the MoU has continued to expand and now involves most of the European coastal states. Indeed, following the continued development of the MoU over recent years similar regional groupings have emerged in other parts of the world.

During the same period the tanker sector and major oil companies made independent provisions for addressing concerns surrounding oil pollution from sea transportation. The tarnished image of the tanker sector has in the aftermath of flagging out shown remarkable improvement, largely credited to the role played by oil majors in inspecting and controlling the maritime tanker industry (ITOPF, 2012; Brown, 2013).

Big oil companies, such as Shell, Texaco and Exxon commonly referred to as oil majors dominate the business. As oil majors are relatively few in number, they enjoy an oligopolistic position in this trade and thus as major clients of oil tanker owners they are able to apply pressures to the outsourced linkages to comply. Because trading oil major cargo yielded higher than average market rate of ship-hire (charter), they were able to exploit the economic imbalance in the business.

In 1970 the oil majors formed the Oil Company International Marine Forum (OCIMF) as a response to increasing public awareness of marine pollution and as an immediate response to the major pollution disaster caused by the tanker Torrey Canyon. The purpose was to provide operational advice and guidelines. In 1993 it was extended to include a safety initiative specifically designed to address concerns about sub-standard tanker operation and maintenance; the Ship Inspection Report Programme (SIRE). This programme involves tanker vetting using a uniform inspection protocol by accredited SIRE inspectors and an inspection report database accessible to OCIMF members and other clients of oil tankers. To ensure that the shipping companies involved in their business maintain high operating and safety standards, oil majors use the SIRE reports to determine the suitability of both the ship and management practice before companies were employment (OCIMF, 2013).

Such regulatory arrangements are embedded in the functionalist argument. As the central economic authority in this trade, the oil majors are arguably the most rational players in monitoring and enforcing regulatory functions that supplemented the state processes in the tanker sector of the maritime industry (Mitchell, 1994). Although they were not seen as a substitute to the state based regulatory structure in the industry, it is no coincidence that they came into prominence during the same period that witnessed a general decline in state-based maritime regulation.

Both of these regulatory institutions do not have rule making capacity and are supplementary to the state based system within a hybridized global shipping regulatory regime. The PSC is an institution that was created out of necessity to provide support for the flag states by inspecting the ships on their behalf. As a large number of ships call at the ports of their own FOC states less frequently (if at all) than the more popular trading ports which also apply rigorous PSC regime (such as the Paris MoU) the PSC acts as a surrogate regulator. In the case of oil majors, the conceptual basis of their role is even further removed from that of the flag states. In fact elsewhere Bhattacharya and Tang (2013) have argued that oil majors cannot substitute the role states (should) play.

In this sense PSC and oil majors are not alone; an intricate network of regulators, such as classification societies, insurance companies and ship builders are among the regulating influences that contribute to and supplement the role of the flag states (Furger, 1997; Mitchell, 1994). DeSombre (2006) pointed out how these influences played a major role in encouraging FOCs to raise their levels of regulatory compliance. Instead of spiralling down to a self-destructing race to the bottom, these supplementary influences helped maintain a great degree of stability in the industry even after the exodus of ship owners to FOCs. In fact it would be prudent to admit that oil majors were able to make use of and build on the existing platform held together by the state/nonstate based actors and raise regulatory inspection and control. Nevertheless, this does not take anything away from the oil majors' regulatory initiative which demonstrates how dedicated functional regulatory initiatives can be highly effective.

It is our intention to analyse how the impacts of two similar yet different regulatory sources (based in functionalism) underpin regulation formation in the shipping industry and help understand the theoretical perspectives regarding formation and implementation of regulation beyond the nation-state. The data sources determine the impacts of the regulations are drawn from those who are regulated, i.e. directors, seafarers and manager, details of which we discuss further in the following section.

\section{Methodology \& methods}

In this section we explain how the study developed an ethnographic constructivist methodology and the extent our approach perceives human understanding as incorporating objective, subjective and relative perspectives. 'Ethnographic studies ... provide social scientific descriptions of people and their cultural bases; in such a way we can develop comprehensions of 'self' in relation to 'other' in terms of becoming' (Howell, 2013: p129). A constructivist ethnographic study develops an integrated synthesis of theory and practice. Indeed, the 'final interpretative theory is multi-voiced and dialogical. It builds on native interpretations and articulates what is implicit in those interpretations' (Denzin and Lincoln, 1994: p120). Constructivist ethnography provides a means of understanding the experiences, beliefs and behaviours of those involved in specific situations. We concentrate on the perspective of those involved in the application of regulation and their definition of 'good'. Through 'thick description and interpretation' we develop an understanding of human existence and social science perspectives at the 
local level (Geertz, 1973). When using this methodological approach it is difficult to draw on all perspectives and such a concentration can omit certain interpretations and variables. Consequently, the study failed to interview inspectors but included secondary data regarding inspection rates, outcomes and safety records.

With the application of this methodology the study conducted interviews between 2006 and 2010, which aimed to develop an in-depth understanding (thick description and interpretation) of the regulatory practice in the maritime tanker industry in its natural context. It involved two oil tanker companies, one trading internationally (WorldCo) and the other in European waters (EuroCo). The companies had approximately 15 ships in each fleet and nearly all were trading oil major cargoes and regularly calling at ports in Europe. As a result they were routinely subjected to PSC inspections and control led by the Paris MoU and oil majors. The flag states of the ships in both companies included TMN as well as FOC. The profiles of the two companies had nothing to suggest that either of them had any feature that was atypical of the maritime tanker industry (see Stake, 2000 for further). The identities of the companies and individuals interviewed are intentionally kept vague due to confidentiality agreements.

The first phase of data was collected in the companies' shore-based technical management offices located in two different cities in Europe. Here a total of 20 management-staff, such as the directors, managers and marine superintendents, were interviewed and company documents studied. The second phase was conducted on-board ships involving four research voyages - two from each company - each lasting for a period of around 10 days. A total of 55 sailing staff were interviewed and documents such as inspection reports and internal correspondences were studies and included. The interview data comprised of over $100 \mathrm{~h}$ of recording each lasting between $30 \mathrm{~min}$ and $2 \mathrm{~h}$.

The purpose of data collection centred on identifying the regulatory practices of PSC and oil majors and investigated the experiences of the regulated in preparing for inspections, understanding the underlying driving factors persuading them to do well in the inspections as well as how inspections were conducted and results of these dealt with. The inquiry limited itself to operational issues such as safety and pollution prevention each of which were the common areas for both regulators assessed as the basis for emerging normative perspectives. Questions included:

- Describe the practice of preparing for the different types of inspections on your ship

- Explain why you would consider one type of inspection more effective than the other

- Describe the role played by the shore-based managers in the context of both inspections

Through semi-structured interviews the respondents were encouraged to elaborate and add their personal views and beliefs when responding to the questions. The analysis involved transcribing and thematically examining transcripts and documents into nodes and categories. Links and patterns between the interviews and documents as well as similarities and variances between the practices of the two types of inspections were carefully examined and analysed (Howell, 2013).

We acknowledge that the data is primarily drawn from the perspective of the regulated. This in itself is not a weakness as it can be argued that matters pertaining to workplace are best understood by the workers. The relative importance of the two major types of inspection, the nuanced differences in their preparations could only be determined by developing understandings in the field. Strauss and Whitfield's (1998) argued that understandings regarding the dynamics of the workplace required natural settings to enable rich data (Piore, 1983). Indeed, to enhance understanding further, future research would need to add the perspectives of the inspectors from the PSC as well as the oil majors.

\section{Findings: relative impacts of the two types of inspections}

In this section we examine the impacts of the different types of inspections through an assessment of a range of managerial and seafarer perspectives. We were clear about why the questions were asked and utilized the knowledge of the sector and insider expertise of one of the interviewers (an ex-Captain in the industry). The possibilities of exaggerated claims by interviewees were closely monitored through the interviewers identifying inconsistencies with key pieces of information. Obviously, interviewees bring subjective tendencies to the research; consequently, triangulation of questions was undertaken and responses continually critically analysed.

Managers and seafarers alike regarded the PSC inspection in Europe as highly effective by using terms such as 'efficient' and 'very thorough'. An example of this general conceptualisation was made explicit by a ship's officer who considered that:

PSC inspectors generally do their job very well. You can't have a poorly run ship and not get caught by a PSC inspector for long.

Approximately one in four foreign ships docking at member state ports are routinely inspected by PSC on the basis of the Paris MoU (Paris, 2012). The ship selection process involve a range of criteria such as flag type and age as well as earlier results of earlier inspections and safety records of both the ship and operating company.

The interviewees from both companies revealed that such inspections in Europe were typically conducted once every year and the process of inspection took around three to six hours. All interviewees indicated that PSC inspections were unannounced and subsequently caused a degree of apprehension for the managers and seafarers.

Apprehensions or fears were rooted in the PSC's ability to detain ships and potential damage to the reputation of individual ships as well as the wider fleet. By pointing to PSC's active publicity mechanism, managers from both companies described how a single unfavourable inspection could strain their relations with other stakeholders including insurance providers and charterers as well as attract additional inspections across the fleet. For instance, one manager from the EuroCo said:

We don't know when it is coming ... we have to assume that it might be in the next port and keep ourselves prepared. While they may not be asking for anything out of the normal if they find a fault we have to pay a heavy price.

Corroboration of management concerns were located in the number of communications sent to shipboard colleagues urging them to remain prepared for negotiating PSC inspections. One such communication read:

[PSC] detention of vessels has far reaching implications that go well beyond the immediate inconvenience and delays associated with rectifying the defects and releasing the vessel. Effects include (a) vessel targeting factor in PSC inspection; (b) serious State response; and (c) most importantly, cessation of commercial use of vessels by oil majors.

In practice both companies performed well with PSC inspections. As one of the managers in WorldCo said:

We have never had a [PSC] detention; never ... in most cases we get two or three or four deficiencies. Nothing happens with small number of easily rectifiable deficiencies. Life goes on.

Likewise, the chief engineer of one EuroCo ship said:

If you are clean [not pumping bilge overboard] and holding regular emergency drills you have no fear from the PSCs even in Europe. The inspection only demands that we do our everyday tasks properly.

While the inspection in itself was not demanding and did not require any special preparation, a lapse on the day, usually associated with substandard shipping, could lead to severe consequences. Thus the objective was to pass inspections and avoid negative attention. This was a constant theme throughout the interviews; 'preparation' was a continual variable and underpinned local adherence to regulatory structures and inspections. 
On the other hand, oil major inspections were conducted following invitations from ship managers. The objective was to obtain approval of the tanker fleet (usually for a period of 12 months), so that they could undertake trade with oil majors' cargo and receive an enhanced hire value in return. But as there was around ten oil majors engaged in maritime transportation, each ship in both companies underwent an inspection every 2-3 months. Each such inspection usually lasted the entire working day and was conducted during cargo unloading operations while in the port. What was also of importance was that even when an oil major did not hire a tanker directly, it was likely to have some involvement along the supply chain link e.g. as the buyer of the cargo or the terminal operator where the ship docks or even as the seller at the wholesale market. Such involvement made oil major approval almost a prerequisite which prompted one of the managers to term the oil majors as 'omnipresent'.

Managers from both companies indicated that for economic viability their primary aim was to ensure that all tankers in the fleet had oil major approval from as many oil major companies as possible. For example a senior manager from EuroCo indicated that:

... an oil major inspection report was the outcome of a thorough professional inspection. To get their approval we have to be one of the best in the market - it works mutually: they expect the best safety standards which we offer by spending significant resources while they give us the best charter rate ... in our weekly office meeting we always discuss the oil major approval status in the fleet - the CEO is keen on that.

Managers were also quick to identify the demanding nature of such inspections by explaining how each inspection required 'weeks of preparation', was resource intensive and invariably demanded follow-up actions such as undertaking repair work, installing new hardware or even making procedural changes to get the company's operating procedures. This exemplified an overwhelming a general perspective regarding the powers associated with oil majors' in this context a WorldCo manager identified his role in the process:

I usually attend one [oil major inspection on one of the ships in the fleet] every month. It is the norm. I fly to the port and help the captain prepare for the inspection. I have developed my own inspection checklist ... Then I need to follow it up in order to close the deficiencies. It is one of the most stressful tasks. There is too much at stake.

Through triangulated questioning during interviews ships officers endorsed the views regarding the intense preparation associated with oil major inspection. The captain of one EuroCo ship enumerated a long list of logbooks that needed to be up-to-date and checks that had to be carried out prior to such inspection and added:

We usually get a week to prepare and you can rest assured that each minutest of mistakes would be found by the [oil major] inspectors ... one major or even too many minor observations lead to a failed outcome. Each observation requires individual attention and care.

Each of those interviewed were explicit regarding the serious consequences of failing an oil major inspection as this threatened the ship's license to carry oil major cargo and thus affected the business plan of the company. Managers of both companies acknowledged performing poorly and even failing in recent oil major inspections which resulted in the incrimination and black-listing of both captains and the shore manager responsible for the ships. Failing an inspection had repercussions for the ship in question as well as approval for others in the fleet. Reflecting available documentation one EuroCo manager explained:

One-year validity is ... the maximum period, not the minimum. We could be inspected several times by the same oil major in a year, for instance before a new short-term contract or using a new terminal. We are pretty much at their [oil majors'] mercy.

Through multiple interviews and documentation it was evident that the thoroughness and high frequency of oil major inspections placed relentless pressure on senior employees. One interviewee called it a 'high stake game' as the resources in terms of investment and time were highly demanding while the consequences of failing were serious. The strength of the oil majors' regulatory mechanism came from the rigorous standard they adopted and the high inspection frequency. Oil major inspections kept managers and seafarers continuously 'on their toes' and ensured they operated their ships at the highest standards because had far greater consequences than the PSC inspections.

A more direct comparison between the two sets of inspection revealed how the standard of oil major inspections was seen as the ultimate and all-encompassing. Given that the stakes were higher when undergoing oil major inspections, a WorldCo manager pointed out:

If we pass this [an oil major inspection] we pass everything ... all other inspections including one by the PSC.

From a logical perspective similar views were made apparent by all interviewees who had personally experienced the two types of inspections. One rating on a WorldCo ship, for instance, said:

From the manager down to me we are always thinking of passing oil majors ... we don't talk of PSC that much.

Indeed archived results from PSC and oil major inspection in Europe further corroborated this view. For example, there were several occasions when the two different types of inspections were conducted on the same ship within a short period of time and in every instance the oil major inspection reports were far more detailed and scrupulous. On one particular occasion one of the EuroCo ships was inspected simultaneously by PSC and oil major in the port of Rotterdam. Corroborating the interview perspectives the two inspection reports were starkly different; the PSC inspector reported only four deficiencies, which were part of a longer list of 20 deficiencies reported in detail by the oil major inspector.

It is important to reflect on the responses from the interviewees which appear to suggest that the oil major and PSC inspections were the only drivers of operational safety and pollution prevention in the two companies studied. As we pointed out earlier, it is not the entire story because the industry benefits from several layers of selfregulation and much of that work goes on behind the scene and is highly likely to be reflected in the outcome of these inspections. But they do not get as much coverage especially from the perspective of the regulated (those at the coalface) negotiating the PSC and oil major inspections. However, we accept that it is possible that the interviewees were excessively sensitive to these two forms of inspection because they were driven by fear of failing (especially those conducted by the oil majors).

That said, while not discounting what may be considered subjective tendencies emerging through the interviews, it is clear that when the two forms of inspections are compared, there appears to be a distinction. The level of preparation demanded by oil majors, the rigour of their inspection process and their impacts as perceived by the regulated were so compelling that there was little room for PSC inspections to demand anything that was not already taken into account. This was despite the case that our chosen region of study was a leading example of PSC effectiveness.

Oil majors involve tight regulations that are functional at an international level. Unlike the PSC, the oil majors do not require an intercontinental dimension. The PSC is less stringent than the oil majors as the latter carry high level economic sanctions for a specific element of the shipping industry. In comparison to the PSC inspection, oil major regulation was considerably distinct and required a different level of compliance although it regulated the same operational issues on ship's safety and pollution prevention. Each involved aspects of functionalism with a distinct normative dimension: oil majors international and PSC inter-continental. Overall, the findings reveal that in a functionalist context both PSC and oil majors had far-reaching impacts in inspecting and controlling the maritime tanker industry. 


\section{Discussion: consistency and coordination}

Overall we considered that the factors that underpin the effective practice of the oil majors involved consistency in their inspections, subsequent control processes and a high level of coordination among the oil majors. The first factor was largely drawn from the oil major's globally coordinated operating procedure starting with strict systems of inspector selection, their training and regular updating of knowledge to inform management of the process under the Ship Inspection Report Programme (SIRE) structure, which allowed for little variation of standards or individual inconsistency.

In this context one of the officers on a WorldCo ship, for instance, remarked:

The preparation effort for all oil majors is the same; there is no difference between the oil majors or even between the same oil major inspections in two different ports'.

Likewise, one EuroCo manager explained:

The oil major inspection follows the SIRE system. The inspector always represents one particular oil major company but that is of little relevance as to which one it is.

The consistency in the oil majors' operating procedure made it possible for the regulated to prepare for a standard that was high but predictable. Such practice symbolises the effectiveness of the functionalist mechanism and if we take into consideration Mitrany's (1975a) it can be suggested that the main causal factor for the effectiveness of the oil majors' regulatory initiative is because it operated from the most appropriate functional level. Indeed, the need for an inter-continental component was necessary but for this to function correctly an international variable in the form of oil majors was required.

On the other hand, we considered that even though the PSC operated under a similar premise it was reliant on a continental dimension. Lack of overarching control in inspector selection, training or consistent operational practice in the inspection process compromised the potential benefits of such a supranational effort. In addition, they were limited to the continental level (Europe) and state interference whereas the oil majors were international. For those regulated the variation in the standard of inspection was readily evident. One of the EuroCo managers with 20 years of experience in PSC inspection in Europe, for instance, indicated that:

PSC inspections across Europe [where we trade] reflect individual inspector's point of view. Mostly it is luck that matters ... Some are so erratic ... if you hold two PSC inspections on the same ship at the same time the reports will be very different ....

The use of state based mechanism by the individual nation states in the European PSC system is inescapable as it was after all the precise objective to directly compensate for the failure of the original form of flagstate regulation. It has a historic relationship with the way in which the regulation in the shipping industry has operated as a state-led initiative but for the same reason the principles of international functionalism cannot be fulfilled in this way.

The relative weakness of the PSC was evident despite decades of maritime expertise of inspection and control mechanism and the infrastructures of states, most of which were TMN. The rationale for such relative ineffectiveness is located in their lack of overarching control and consistency over the regulatory system. The European level is more effective than state based regulation but not as comprehensive as the oil majors international dimension which supports a functionalist argument. We observe both a continental an international based institution and found that the PSC is unable to function at the international level where the oil majors can. This goes back to the historical connection between a regulation and its territorial limits. In the case of Europe the extra territoriality was achieved because of structural and institutional changes, but in the current paradigm of regulation it could not be extended further. The maritime oil industry is built on the premise of international trade with its footing firmly placed across the world. The key feature of such oil major's private governance by inspection and enforcement is territorially inconsequential.

Also important was the coordination in the inspections and control by both the PSC and oil majors. A principle operating strategy in the European PSC was rooted in high levels of coordination among the member states in sharing of the data from inspections. Deficiencies identified on a ship were thus shared among the member states such that the ship could be monitored and if required further inspected whenever it subsequently called another port in the region. The PSC in Europe thus posits as a highly effective example of neo-functional regulatory practice.

A similar level of coordination was also emulated by the oil majors. Sharing of data on inspection reports among the users of the SIRE scheme was a core feature of the system. The knowledge about the inspection result thus does not stay confined to between the ship and the specific oil major. One manager described the whole practice as 'impenetrable' and said:

We can't say that we would only have our ship inspected by Shell and carry their cargo. It is not that Shell is easier than BP. They all are of the same standard - we can't choose just one. They share reports between them - so if today one reports a defect the next one would go on board and inquire of the same defect [first].

We have little evidence that reports are shared by oil majors but it would be a logical position and one that interviewees considered realistic. That said, the sharing of inspection reports among the oil majors can appear counterintuitive because the number of 'safe' ships are not endless and hiring them is evidently good for the reputation of the oil majors. However, the oil majors did not consider that critical in their business and converged under the SIRE system.

Grant and Marsh (1977) and Marsh (1978) provide an explanation to the rationale for why companies competing in a common market might refrain from direct competition in certain aspects. The authors point out that there are benefits for joining common interest groups not only for services or selective incentives but for collective goods. These could include political lobbying involving regulatory change affecting the entire industry (Moe, 1980) or as has been identified by (Bhattacharya and Tang, 2013) it is ecopolitics in the maritime tanker sector that prompts the oil majors to join forces when monitoring and enforcing regulation. The pollution of 'ocean space' brings disrepute to the entire industry which potentially affects the oil trading community and not stay confined just to the oil major in question. Awareness in sustainability, ecopolitics and environmentalism has led to pressures from the public and political implications beyond the immediate market. For the oil majors, the rationale for complying with social and environmental regulations is thus more compelling than what could otherwise be gained by competing against one another. This reiterates DeSombre's (2008) point regarding the 'club effect' which already exists in the industry. Just as Protection and Indemnity (P\&I) Clubs and Classification Societies find mutual benefit by sharing information and discouraging destructive competition among the club members, the oil majors share a similar philosophy.

\section{Conclusion}

This ethnographic constructivist study of international maritime tanker industry provides compelling evidence of the relative effectiveness of functionalism in both inter-continental and international contexts. Both forms of monitoring and enforcement of regulation in the maritime tanker sector were initiated around the same time. The commercially operated regulatory mechanism followed the international principles of functionalism and operated independent of the state instruments while the implementation of PSC in European waters provided the basis for an inter-continental perspective. Each identified a means of understanding the construction of ocean space that did not necessitate a totally 'realist' perspective. However, even though an international dimension exists, regulation is still determined through social 
constructions and these adhere to localities in terms of continents and industries. Consequently, a global regulator related to specific territory had not emerged and this would not occur until different understandings of international relations were apparent. Ocean space involves a social construction and conceptualisation of this space is central to "the institutions and structures that govern ... lives' (Steinberg, 2001; p191). Space is still perceived through the prism of territory and regulation of this space continues to be located in acceptable constructed structures or discourses.

Both PSC and oil majors were influential in reversing regulatory decline but originated from two different elements of the theoretical perspective. The former was imposed as a statutory requirement in Europe and operated from the standpoint of a neo-functional perspective and provided the basis for inter-continental aspects of functionalism. While the latter was exerted by the powerful leaders of an exclusive supply chain and acted within an international space. In general, the interviewees considered the latter more effective. The PSC availed decades of maritime expertise of the TMN and a high level of coordination among the member states while the oil major led regulation did not enjoy the same level of institutional maturity. Their regulatory practices excelled due to the effective and regular application of inspection and control of existing regulation at an international rather than regional level. Through each institution both aspects of functionalism are realised in the shipping industry in terms of intercontinental and international levels. This is not the first time that PSC has been deficient in addressing pollution concerns in the shipping industry. Mitchell (1994) reveals the reluctance of the port states to impose punitive measures often because of a lack of convincing evidence to make a legal case. There was also a limit to how much resource state agencies were able to invest when identifying violating seafarers or ship-owners.

Finally, the study also suggests that functionalism in the context of the shipping industry has undergone a metamorphosis in terms of normative underpinning; rather than identifying peace as the basis of nonstate regulatory initiative it is triggered by wider populist views on green politics and environmental sustainability. This paper considers that through the protection afforded the natural world (ocean space) through functionalist agencies and regulation the idea has developed an ethical perspective beyond its original remit of peaceful order and the exploitation of the freedom of the seas for unfettered trade (McGonigle and Zacher, 1979). The shift in the normative perspective probably explains our increased consideration toward the environment which is more pronounced than a more generalist ideal of peaceful coexistence. Environmentalism is not new in the history of regulatory influence in the tanker sector. Throughout the 1970s and 1980s the pressures to address harmful environmental effects resulted in installing expensive new equipment in the tanker sector. Building ships with void chambers and separating cargo and ballast spaces in the oil tankers were some of the products (Mitchell, 1994). Such impacts are less evident in other sectors of the maritime industry, such as in bulk or container trade, arguably because they don't trade environmentally sensitive cargoes.

While environmentalism may act as the precondition for functionalist regulatory initiation, its effectiveness is scripted by the mechanisms on which it relies. Through understanding the implementation of regulation based on functionalism we can identify the effectiveness of intercontinental and international regulatory structures. As Mitrany noted, Europe would not be able to deal with the international arena and required coordination with other states. However, in a globalized world it is evident that we are not speaking of other states but an industry led institution based on normative factors relating to environmentalism and safety. Profit provides the driver for effective regulation but a functional international mechanism enables effective regulation for shipping in one specific sector 'oil'. Ocean space and mobilities are constructed through normative considerations that rely on agencies beyond the nation-state and implementation of regulation through functional variables.

\section{References}

Aglietta, M., 1976. A Theory of Capitalist Regulation: The US Experience. Verso, London, New York.

Alderton, T., Winchester, N., 2002. Globalisation and de-regulation in the maritime industry. Mar. Policy 26, 35-43.

Bhattacharya, S., Tang, L., 2013. Fatigued for safety? Supply chain occupational health and safety initiatives in shipping. Econ. Ind. Democr. 34 (3), 382-398.

Boisson, P., 1999. Safety at Sea: Policies, Regulations \& International Law. Bureau Veritas, Paris.

Braithwaite, J., Drahos, P., 2000. Global Business Regulation. Cambridge University Press, Cambridge.

Brown, H., 2013. Global oil spill trends. Lloyd's List (31 January).

Cariou, P., Meija Jr., M.Q., Wolff, F., 2008. Transportation Research Part E: Logistics and Transportation Review 44 (3), 491-503.

Cidell, J., Pryterch, D. (Eds.), 2015. Transport, Mobility and the Production of Urban Space. Routledge, Abingdon and New York.

Coyle, D., 2000. Head of the WTO Cited in the Independent 17th June 2000. p. 19.

Cresswell, T., Merriman, P. (Eds.), 2011. Geographies of Mobilities: Practices, Spaces, Subjects. Ashgate, Farnham and Burlington VT.

Denzin, N., Lincoln, Y., 1994. The Handbook of Qualitative Research. Sage Publications, Thousand Oaks, CA.

DeSombre, E., 2006. Flagging Standards: Globalisation and Environmental, Safety, and Labour Regulations at Sea. MIT Press, Cambridge, MA.

DeSombre, E.R., 2008. Globalization, competition, and convergence: shipping and the race to the middle. Glob. Gov, 14, 179-198.

Fan, L., Luo, M., Yin, J., 2014. Flag choice and port state control inspections - empirical evidence using a simultaneous model. Transp. Policy 35, 350-357.

Furger, F., 1997. Accountability and systems of self-governance: the case of maritime industry. Law and Policy 19 (4), 445-476.

Geertz, C., 1973. The Interpretation of Cultures. Basic Books, New York.

Gereffi, G., Humphrey, J., Sturgeon, T., 2005. The governance of global value chains. Rev. Int. Polit. Econ. 12 (1), 78-104.

Gibbs, C., McGarrell, E.F., Axelrod, M., 2010. Transnational white-collar crime and risk: lessons from the global trade in electronic waster. Criminology \& Public Policy 9, 543-560.

Giddens, A, 1999. Runaway World. Profile Book, UK.

Gold, E., 1981. Maritime Transport: The Evolution of International Marine Policy and Law. Lexington, Massachusetts.

Grant, W., Marsh, D., 1977. The Confederation of British Industry. Hodder and Stoughton, London.

Grey, M., 1996. Just why the policeman must be fair. Lloyd's List (10th April).

Grey, M., 2007. Equasis sets down state of world fleet. Lloyd's List (08 January).

Gunningham, N., 1998. Towards innovative occupational health and safety regulation. Journal of Industrial Relations 40 (2), 204-231.

Gunningham, N., Grabosky, P., 1998. Smart Regulation: Designing Environmental Policy. OUP, Oxford.

Gunningham, N., Rees, J., 1997. Industry self-regulation: An institutional perspective. Law and Policy 19 (4), 363-414.

Gunningham, N., Sinclair, D., 1999. Integrative regulation: a principle-based approach to environmental policy. Law and Social Inquiry 24 (4), 853-896.

Gunningham, N., 2007. Mine safety: law regulation policy. Annandale (NSW). Federration Press.

Haas, E.B., 1958. The Uniting of Europe. Stanford University Press, USA.

Habermas, J., 2006. In: Cronin, C., Pensky, M. (Eds.), Euroskeptism, Market Europe or a Europe of World Citizens in Time of Transition. Polity Press, Cambridge UK, pp. 73-88.

Hay, C., Marsh, D. (Eds.), 2000. Demystifying Globalization. University of Birmingham UK, Polsis.

Heija, C., Bijwaardb, G.E., Knapp, S., 2011. Ship inspection strategies: effects on maritime safety and environmental protection. Transp. Res. Part D: Transp. Environ. 16 (1), $42-48$.

Held, D.D., McGrew, A.G., Goldblatt, D., Perraton, J. (Eds.), 1999. Global Transformations. Polity Press, Cambridge, UK.

Howell, K.E., 2013. An Introduction to the Philosophy of Methodology. SAGE Publications, London.

ILO, 2001. The Impact on seafarers' Living and Working Conditions of Changes in the Structure of the Shipping Industry. ILO, Geneva.

ITOPF, 2012. International Tanker Owners Pollution Federation Statistics. Available Online http://www.itopf.com/information-services/data-and-statistics/statistics/index. html (Accessed 08 Sep '12).

Jessop, B., Sum, N.-L., 2006. Beyond the Regulatory Approach: Putting Capitalist Economies in Their Place. Edward Elgar, Cheltenham UK

Johnson, D.M., 1988. The Theory and History of Ocean Boundary-making. McGill-Queens University Press, Canada.

Lowry, N., 2007. EMSA calls for PSC inspection changes. Lloyd's List (25 April).

Majone, G., 1990. Deregulation or Re-regulation? Regulatory Reform in Europe and the United States. Frances Pinter, London, pp. 1-2.

Majone, G., 1996. A European regulatory state? In: Richardson, J.J. (Ed.), European Union Power and Policy-making. Routledge Press, London and New York

Marsh, D., 1978. More on joining interest groups. Br. J. Polit. Sci. 8, 380-384.

McGonigle, R.M., Zacher, M.W., 1979. Pollution, Politics and International Law. UCP, Berkley.

Mitchell, R.B., 1994. Regime design matters: intentional oil pollution and treaty compliance. Int. Organ. 48 (3), 425-458.

Mitrany, D.A., 1943. Working Peace System. Royal Institute of International Affairs, London. 
Mitrany, D.A., 1975a. In: Groom, P., Taylor, A. (Eds.), A Political Theory for a New Society in Functionalism. University of London Press, London, pp. 25-37.

Mitrany, D.A., 1975b. In: Groom, P., Taylor, A. (Eds.), Functionalism: Theory and Practice in International Relations in Functionalism. University of London Press, London.

Mitrany, D.A., 1975c. The Functional Theory of Politics. London School of Economics Press, London.

Moe, T.M., 1980. The Organisation of Interests. University of Chicago Press, Chicago.

OCIMF, 2013. Sire Inspector Training and Accreditation Guideline. Available Online http://www.ocimf.com/SIRE/Sire-Documents (Accessed 08 Sep '12).

Ozcayir, Z.A., 2001. Port State Control. LLP, London.

Paris, M.U., 2012. Port State Control Annual Report. Available Online http://www. parismou.org (Accessed 08 Sep '12).

Piore, M.J., 1983. Qualitative research techniques in economics. In: van Maanen, J. (Ed.), Qualitative Methodology. Sage Publication, Beverly Hills.

Sampson, H., Bloor, M., 2007. When Jack gets out of the box: the problems of regulating a global industry. Sociology 41, 551-569.

Selznick, P., 1985. Focusing organizational research on regulation. In: Noll, R. (Ed.), Regulatory Policy and the Social Sciences. University of California Press, Berkeley and Los Angeles.

Sewell, J.P., 1966. Functionalism and World Politics. Princeton University Press, California USA.
Siems, M., Schinder, G., 2014. Ordoliberalism lessons for economic stability: different kinds of regulation not more regulation. Governance: An International Journal of Policy Administration and Institutions 27 (3), 377-396.

Sinclair, D., 1997. Self-regulation versus command and control? Beyond False Dichotomies. Law and Policy 19 (4), 529-559.

Stake, R.E., 2000. Case studies. In: Denzin, N.K., Lincoln, Y.S. (Eds.), Handbook of Qualitative Research. Sage Publications, Thousand Oaks.

Steinberg, P.E., 2001. The Social Construction of the Ocean. Cambridge University Press, Cambridge UK.

Stigler, G., 1971. The theory of economic regulation. The Bell Journal of Economics and Management Science 12 (1), 3-21.

Strauss, G., Whitfield, K., 1998. Research methods in industrial relations. In: Whitfield, K. Strauss, G. (Eds.), Researching the World of Work: Strategies and Methods in Studying Industrial Relations. Cornell University Press, Ithaca.

Tranholm-Mikkelson, J., 1991. Neo-functionalism obstinate v obsolete. Millennium: Journal of International Studies 20, 1-22.

van Erp, J., Huisman, W., 2010. Smart regulation and enforcement of illegal disposal of electronic waster. Criminology \& Public Policy 9, 579-590.

Walters, D., James, P., 2009. Understanding the Role of Supply Chains in Influencing Health and Safety at Work. IOSH, Leicester. 